EGU21-4054

https://doi.org/10.5194/egusphere-egu21-4054

EGU General Assembly 2021

(c) Author(s) 2021. This work is distributed under

the Creative Commons Attribution 4.0 License.

\title{
The genesis of gold in Sb-As and Sb-Au ore veins, new constraints from the study of the La Bellière and La Lucette districts (Armorican Massif, France)
}

\author{
Florent Cheval-Garabédian ${ }^{1,2}$, Eric Marcoux ${ }^{1}$, Jérôme Gouin ${ }^{3}$, Maxime Picault ${ }^{4}$, and Michel Faure ${ }^{1}$ \\ ${ }^{1}$ University of Orléans, ISTO, France (florent-cg@hotmail.fr) \\ ${ }^{2}$ Present address: Société Minière Georges Montagnat, 30 route de la Baie des Dames, 98800 Nouméa, Nouvelle-Calédonie \\ ${ }^{3}$ Pole Avenia, Hélioparc, 2 Avenue du Président Pierre Angot, 64000 Pau, France \\ ${ }^{4}$ Variscan Mines, 10 rue Léonard-de-Vinci, 45074 Orléans Cedex 2, France
}

Shear zones hosted antimony (Sb) quartz vein-type deposits are the most important sources of $\mathrm{Sb}$ worldwide. They have been recognized and mined since the Antiquity in the European Variscan belt, and particularly in the French Variscan Massifs, as the Armorican Massif. Among this type of deposit two subtypes are identified, i) the $\mathrm{Sb}$ and gold ( $\mathrm{Au}$ ) quartz vein-type (Sb-Au) as the La Lucette deposit located in the North Armorican Domain, and ii) the Sb-As quartz vein-type as those from the la Bellière district in the Ligerian domain.

The recent advances in the understanding of the Sb mineralizations in the European Variscan Belt are typically focused on the $\mathrm{Sb}$ ore-genesis and its regional implications, ignoring its potential valuable co-products as gold. In this study, detailed textural-mineralogical investigations coupled with geochemical analyses in rock-samples with in-situ EPMA and LA-ICPMS ore-minerals trace element analyses, were carried out for the first time in the Late-Variscan mineralizations from the La Bellière Sb-As occurrences, and the La Lucette Sb-Au deposit, to ascertain the distribution and amount of $\mathrm{Au}$ in the ore-minerals and provide new data on ore deposition conditions.

In the La Bellière Sb-As occurrences, no visible gold has been observed, but low-grade gold, ranging between 0.2 to $1 \mathrm{~g} / \mathrm{t} \mathrm{Au}$, are correlated with high-grade As in rock sample. In the La Lucette $\mathrm{Sb}-\mathrm{Au}$ deposit, historical assays have shown high-grade gold with an average at $40 \mathrm{~g} / \mathrm{t}$ Au. EPMA and LA-ICP-MS analyses have demonstrated that gold is already present during the early time of the mineralization as invisible gold, trapped in the lattice of the Sb-rich arsenopyrites, with an average grade of $70 \mathrm{ppm} \mathrm{Au}$ in La Bellière, and at higher average grade of $223 \mathrm{ppm}$ Au for La Lucette. For both type of mineralization, the early invisible gold is concentrated preferentially in the borders of the arsenopyrite crystals, and is correlated with an increase of the As content, and a decrease of the $\mathrm{Sb}$ and $\mathrm{Fe}$. We argue that gold could be added in the arsenopyrite by substitution with the Fe and $\mathrm{Sb}$ at high temperature $>300^{\circ} \mathrm{C}$.

Visible gold corresponds to the economic gold ore of the Sb-Au mineralizations. In the La Lucette ore, it is emplaced in the late stages, as discrete electrum grains spatially associated with the 
arsenopyrites, as native gold inclusions within the stibnite, and associated with rare aurostibite. Remobilization processes of the gold-bearing arsenopyrite at lower temperature, coupled with a minor initial enrichment of the Sb-bearing ore-fluid might be responsible of the late high-grade gold ore, and the visible expression of this element. In the absence of such remobilization process with late ore-fluid-enrichment, only low-grade gold is present, under the form of invisible gold in auriferous-arsenopyrites.

The presence of a valuable gold co-product, also present in the Sb-As mineralizations, unknown until now in the French Variscan Massifs, will improve its economic attractivity. Gold potential in the huge French Sb-districts as the Vendée or the Brioude-Massiac districts must be reassessed. 